\title{
TESTIMONIOS RELIGIOSOS EN LAS MINAS DE RIOTINTO: ALGUNAS REFLEXIONES
}

\section{RELIGIOUS TESTIMONIES FROM THE RIOTINTO MINES: SOME THOUGHTS}

\author{
por
}

\author{
MERCEDES ORIA SEGURA
}

RESUMEN Revisamos un lote de figuras de piedra y bronce y una inscripción latina, referibles a las creencias religiosas vigentes en la cuenca minera de Riotinto (Huelva), desde poco antes de la conquista romana hasta plena época imperial. La adscripción de varias de las piezas a divinidades prerromanas resulta difícil por los problemas de identificación de la población local, en el marco de los problemas históricos que afectan a la Beturia Céltica; y por la afluencia de emigrantes (mayoritariamente lusitanos) que trabajan en las minas. Proponemos la creación "artificial", a efectos de control político por parte de las autoridades romanas, de un centro de culto dedicado al dios lusitano Endovélico. Los testimonios de carácter inequívocamente romano hablan de cultos de base popular, que tienen su expresión más directa en la existencia de un colegio funerario bajo la protección de Júpiter.

\begin{abstract}
We review a series of stone and bronze figures and a Latin inscription, referred to religious beliefs in the mining district of Riotinto (Huelva), from a short time before the Roman conquest, until Imperial age. The adscription of some of them to pre-Roman gods becomes difficult, because local population is not well identificated, as a part of the historical problems that affect the neighbour region of Baeturia Celtica, and partially as a consequence of the great affluence of Lusitanian people, emigrated to work at the mines. We propose the "artificial" creation, with political control purposes, of a cult centre devoted to the Lusitanian god Endovelicus. Clearly Roman testimonies talk about "popular" religion, reflected in the existence of a funerary college under the protection of Jupiter.
\end{abstract}


La presencia romana en las minas onubenses, especialmente en Riotinto, cuenta con una amplia bibliografía (véase en Domergue 1987 y 1990), centrada en los aspectos técnicos y económicos con referencias al social. En las minas se asienta una población heterogénea: trabajadores locales y emigrantes sobre todo galaicos y lusitanos (remitimos a las inscripciones $C I L A$ In $^{\circ} 28-46$ ), así como un pequeño contingente de militares y administradores enviados desde la capital. Pero una manifestación tan representativa de su diversidad como la religión ha sido poco tratada. Sólo González y Pérez Macías (1986: 291-295) repasan los testimonios de culto prerromanos y romanos de la provincia, sin detenerse específicamente en la zona minera. Un estudio reciente, añadiendo algunos otros bronces al material aquí analizado, plantea la existencia de un santuario en Riotinto (Cuenca 1996: 50-57). Los objetos son escasos, pero expresivos de un vivo contraste con las muestras de religiosidad en la campiña y la costa de Huelva, donde la base económica y social es muy distinta. Nuestro estudio trata de integrar estos materiales en el contexto histórico que les da sentido, como testimonio de la forma en que las autoridades romanas aprovechan las creencias prerromanas como elemento de control.

Los testimonios alusivos a la religión son heterogéneos y de diverso valor, sobre todo los referidos a dioses clásicos. Los usos de la iconografía mitológica en todos los ámbitos de la vida romana obligan a tomar con reservas objetos como el Silvano de bronce de El Berrocal, o la gema con los atributos de Fortuna de Nerva. Pero ante la escasez de otras manifestaciones más seguras, evidencian al menos que ciertas divinidades son conocidas. Presentaremos el material según su posible adscripción a cultos prerromanos o romanos, para realizar después una valoración general ${ }^{1}$.

\section{OBJETOS RELACIONABLES CON CULTOS PRERROMANOS}

Dos bloques de gossan presentan cabezas en altorrelieve. La primera (lám. I), de 0,54 x 0,38 x 0,35 m, es de rostro redondo, ojos almendrados, nariz chata, carrillos abultados y orejas puntiagudas, con cuernos o una corona de hojas. La otra (lám. II), con $0,66 \times 0,34 \times 0,22 \mathrm{~m}$, es ovalada, de ojos redondos, nariz larga de fosas marcadas, orejas alargadas muy altas y una corona o diadema entre los cuernos (Blanco 1962: 40, figs. 10-11). Proceden del Cerro Salomón y Blanco las atribuyó a un santuario (identificado por Luzón 1974: 316 con los restos romanos de la cúspide), relacionándolas con el dios galaico Vestio Alonieco, del que se conocen dos inscripciones (ILER 949 y 950) y un relieve de Lourizán (Pontevedra): una figura de rostro afilado y barbado, con los brazos abiertos y dos largos cuernos triangulares muy abiertos (Bouza 1946: 110-116 figs. 4-5).

Una pieza muy conocida es el jabalí de bronce de $25 \mathrm{~cm}$ de longitud, procedente del escorial de $\mathrm{S}$. Carlos y actualmente en Gran Bretaña (Rodríguez Oliva 1993: 45), del que se conservan copias en los Museos de Huelva y Riotinto (lám. III). Se interpreta como un objeto de decoración doméstica, o más probablemente como un exvoto dedicado a Endovélico, según explicaremos. Además se conserva en Riotinto otra figurilla animal muy mutilada, quizás una cabra semejante a las que aparecen en ambientes célticos del cercano Alentejo (Berrocal 1992: 127-129 y fig. 22.4-8), de 4,5 cm de altura (lám. IV) y realizada también en bronce, que podría interpretarse de forma parecida.

Destaca la escasez de referencias a los cultos púnicos, dada la atención que las minas de Riotinto despiertan desde la más antigua época colonial. González y Pérez Macías (1986: 292) mencionan una figura de elefante de dudoso contenido religioso y la estela de Tharsis, el otro gran núcleo minero onubense (García y Bellido 1942: 294, fig. 57). Luzón (1974: 319) añade otros objetos orientalizantes también de Tharsis, parte quizás

1. Agradezco vivamente a $D^{a}$ Elena Aguilera, del Museo Minero de Riotinto, y $D^{a}$ Juana Bedia, del Museo Provincial de Huelva, las facilidades a la hora de estudiar el material en ellos conservado; así como las indicaciones de la Prof. Ma Cruz Marín, del Dpto. de $\mathrm{H}^{\mathrm{a}}$ Antigua de la Universidad de Sevilla. 
de un ajuar funerario, de los que desconocemos otros datos: una figurilla de bronce de diosa con las manos en los pechos y un collar de oro con palmetas y rosetas, ambos de propiedad privada. No nos ocuparemos aquí de estas piezas, que pertenecen a una zona diferente.

\section{MATERIALES RELATIVOS A LA RELIGIÓN ROMANA}

Los testimonios relativos a los cultos romanos no son más numerosos. Luzón (1974: 316) proponía identificar los restos constructivos romanos en el Cerro Salomón con un centro de culto común para el núcleo minero. La interpretación es probable por la propia posición dominante del cerro, pero las dos cabezas en relieve allí encontradas indican más bien un origen prerromano. La pervivencia en época romana no sería extraña, tal como se constata en santuarios de ambiente parecido (Berrocal 1992: 192-194), de forma muy destacada en el extremeño de Capote (Berrocal 1989-90: 117-119). La identificación del dios indígena o romano venerado en Riotinto permanece abierta.

La única inscripción votiva la dedica a Júpiter Óptimo Máximo un colegio funerario de la segunda mitad del s. II o s. III d.C., toscamente trazada sobre una placa fragmentada de mármol blanco con vetas rojizas, de $27 \times 37,5 \times 1,5 \mathrm{~cm}$ : Ioui - Optumo/Maxumo - Colle/gium - Salutarem (CILA I n ${ }^{\circ} 28$, con toda la bibliografía anterior) (lám. V). Se encontró durante labores mineras y se conserva en el Museo Provincial de Huelva.

$\mathrm{El}$ resto lo forman figuras de bronce. En primer lugar destaca una muy desgastada con pátina verdosa, de $6,3 \mathrm{~cm}$ de altura: un Marte desnudo, con casco de alta cimera y clámide al hombro izquierdo, alzando el brazo derecho (lám. VI). Se halló en "La Marismilla", (Riotinto), durante trabajos de prospección y se expone en el Museo Minero de Riotinto (Oria-Escobar 1994: $455 \mathrm{n}^{\circ} 12$, fig. 3.12).

También se encontró en las minas, a fines del s. XIX o principios del XX, una estatuilla que debe representar a Fortuna. Ha perdido sus atributos excepto el extremo inferior de la cornucopia en el brazo izquierdo (Nash 1904: fig. s.n ${ }^{\circ}$, sin referencias en el texto) (lám. VII). Desconocemos cualquier otro dato acerca de ella, así como su paradero actual.

Otra pieza semejante es el Silvano de propiedad particular, que se encontró en los alrededores de Riotinto (Oria-Escobar 1994: $457 \mathrm{n}^{\circ} 18$ ). Su uso religioso es inseguro, mientras resulta más probable que sea un exvoto la mano izquierda en bronce, de $18,8 \mathrm{~cm}$ de altura, extendida y con un orificio en la muñeca, que se encuentra hoy en el Museo Provincial de Huelva (Bronces 1990: $218 \mathrm{n}^{\circ}$ 103) (láms. VIII-IX). Recientemente se ha interpretado como remate de una especie de estandarte, destinado a las procesiones dedicadas a Júpiter Dolicheno (Perea 1995). El Museo Minero de Riotinto (Sala de Roma, vitrina $9 \mathrm{n}^{\circ} 17$ ) conserva además un amuleto fálico de bronce, testimonio de una práctica habitual en la vida cotidiana ajena ya al ámbito puramente cultual. Probablemente también lo es el colgante de hueso en forma de pie ( $2,1 \mathrm{~cm}$ de longitud) del mismo Museo (lám. X), aunque no pueda descartarse su interpretación como exvoto anatómico, igual que la mano de bronce.

La última pieza relacionable con dioses romanos en la zona es un ágata de época augustea procedente del Cerro del Moro (Nerva), que muestra una cornucopia con un cetro y una pátera (Martínez-Pavón-Lorenzo 1991: $149 \mathrm{n}^{\circ} 3$, 154 fig. 3). La pátera alude directamente a ceremonias cultuales y ambos atributos corresponden a divinidades como Felicitas y Fortuna, en general a aquellas que proporcionan riqueza y prosperidad, que el propietario de la gema buscaría propiciar, dado el frecuente uso de las gemas como amuletos (Casal 1990: Introducción). El Cerro del Moro sólo se ocupa en época augustea, hasta comienzos del reinado de Tiberio (Martínez-Pavón-Lorenzo 1991: 152), cronología que concuerda bien con el estilo del entalle.

No se documenta en Riotinto un culto imperial organizado, aunque existe una dedicatoria honorífica a Nerva por un liberto y procurator ( $C I L A$ I $\left.^{\circ}{ }^{2} 29\right)$, cargo que desde Vespasiano sitúa las minas béticas bajo control imperial directo (Domergue 1990: 292 y n. 67); y otra posible dedicatoria a un emperador 
tardío (CILA I n ${ }^{\circ} 30$ ). Fuera de la zona, contamos con esculturas como el thoracato de Tharsis (Acuña 1975: $98 \mathrm{n}^{\circ}$ XXII, láms. 70-72). Al encuadrarse los sacerdocios del culto imperial en las estructuras municipales, ausentes en la zona, no podemos esperar en Riotinto flaminados o seviratos, mientras no se han conservado dedicatorias, ni siquiera privadas, a emperadores divinizados.

\section{LA VALORACIÓN DE LOS MATERIALES}

Según indicábamos, los datos sobre creencias religiosas en las minas de Riotinto son escasos y heterogéneos. Identificar a las divinidades veneradas es un primer problema, conectado con la caracterización de los propietarios y dedicantes de los objetos reseñados.

La comarca minera de Riotinto se encuentra fuera de los límites, pero en el área de influencia de una región que aún hoy plantea complejos problemas geográficos, históricos y culturales: la Beturia Céltica (García Moreno 1971: 106; Berrocal 1992; Celtas y túrdulos 1995, etc.), que a grandes rasgos coincide con la cuenca media-baja del Guadiana y que según Plinio (NH III, 13-14) estaba habitada por celtíberos venidos de Lusitania. Lorrio (1995: 107-108 especialmente) sitúa a estos grupos célticos hacia el actual Alentejo, basándose en la información de Polibio recogida por Estrabón (III, 1,6). Célticos del S.O. y lusitanos son equiparados en las fuentes antiguas, que resaltan el apoyo encontrado por Viriato en la Beturia, según Berrocal por su "parentesco étnico y cultural" (Berrocal 1989-90: 105 y 1995: 154, sobre Viriato; contra, Gorrochategui 1987: 77-91 y 1990: 418-422, con argumentos lingüísticos). El hecho es que, según indican Herodoto (II, 33), Avieno (OM 195-204) y sobre todo Estrabón (III, 1, 6), dentro de Lusitania existen núcleos de población celta, fruto según Almagro-Gorbea (1990: 121 ss.) de un sustrato "protocéltico", más arcaico que las culturas célticas centroeuropeas, presente en todo el Occidente peninsular hasta el Guadalquivir y manifestado en elementos materiales e ideológicos, de los que destacan las divinidades galaico-lusitanas.

En el caso de Riotinto el problema consiste en la falta de datos, como han puesto de manifiesto recientes estudios sobre el mundo céltico peninsular. Apenas sabemos nada sobre sus habitantes prerromanos, aunque en las minas se trabaja al menos desde principios del Calcolítico (Domergue 1990: 108, remitiendo a Blanco Rothenberg 1981). Recordamos de paso la importancia de la actividad minera y metalúrgica en la Celtiberia (Canto 1995: 304-309), aunque la epigrafía onubense no recoge personas de este origen y sí numerosos lusitanos. Es bastante probable que la población prerromana pertenezca a ese ámbito céltico, que Gamito (1988: 95 ss.) pretende extender prácticamente a todo el S.O. con argumentos literarios, lingüísticos y arqueológicos. La preferencia de estos pueblos por un hábitat rural disperso (Estrabón III, 2, 15) explicaría en parte las escasas huellas dejadas por la población local. La atribución de los objetos de carácter religioso a unas divinidades $u$ otras se ve directamente influida por esta compleja cuestión.

Respecto a los relieves, los autores más recientes (Cuenca 1996: 53-54; Berrocal 1992: 61) admiten la identificación con el dios galaico Vestio Alonieco propuesta por Blanco, sobre bases iconográficas muy débiles. Gamito (1988: 126-127, fig. 29.1-2), sin llegar a ello, considera sin duda las dos cabezas como célticas, imágenes del dios titular del santuario. La similitud entre Vestio Alonieco y el galo Cernunnos (identificado por Blázquez 1977: fig. 134 en un vaso pintado de Numancia), otra divinidad con cuernos acompañada de símbolos solares y con atribuciones sobre las fuerzas vitales del sol y la tierra (Tranoy 1981: 290-291), llevarían a considerarlo una divinidad ctónica, cuyo culto sería difundido en Riotinto por los mineros de origen galaico. En todo caso, la iconografía es tan insegura como la cronología. El relieve de Lourizán con Vestio Alonieco puede ser de los ss. II-I a.C., mientras los de Riotinto no tienen datación precisa. El aspecto común de todos ellos se debe más a su tosquedad que a rasgos bien definidos, pero en cualquier caso es verosímil relacionarlos con las imágenes célticas. No podemos olvidar que en ambientes célticos de toda Europa se representan las características cabezas aisladas (Marco 1990: 496-498). Pero si 
los relieves contribuyen a identificar como santuario una construcción de cierta envergadura, situada en una altura dominante (para Cuenca 1996: 53 serían sillares integrados en la estructura del edificio), es más probable que éste se dedique a un culto de fuerte arraigo, y no a un dios escasamente documentado incluso en su zona de origen.

Más difícil resulta identificar las cabezas con el dios prerromano más venerado en el S.O., el lusitano Endovélico. De éste se conservan cuatro imágenes (Blázquez 1983: 284-285; EREP nº 127-128) mucho más humanizadas y sin cuernos. Endovélico es un dios relacionado con animales, desde la etimología propuesta para su nombre (*uailo, "el lobo", con el superlativo andei-, pero también *uell, "bueno") hasta su asociación con la cabra y otros animales en los exvotos prerromanos y el jabalí en los de época romana. Esta divinidad se difunde en el bajo Guadiana y su principal centro de culto se encuentra en S. Miguel de Mota (Alandroal, Évora), en plena zona céltica de la Lusitania. El considerar a Endovélico céltico (Gamito 1988: 130-131; Marco 1990: 489-490; Berrocal 1992: 60-61) o lusitano no céltico (Canto 1995: 309) plantea cierta controversia, como la propia caracterización de los lusitanos. Se venera también mucho más al N., en la vettona provincia de Ávila (en Postoloboso, Candeleda) con el nombre de Vellicus o Vaelicus (Fernández 1973), por una mayoría de indígenas que se identifican mediante el uso de un gentilicio (Marco 1990: 489490). En la propia provincia de Huelva el nombre de la comarca del Andévalo, precisamente donde se sitúan las minas, remite al del dios (González - Pérez Macías 1986: 292; Fernández 1973: 230). Las ruinas en el cerro del mismo nombre se consideraron parte de un templo (ya en Ceán 1832: 260). Las piezas más claramente relacionables con Endovélico en Riotinto son el jabalí y la posible cabra de bronce, que pueden identificarse como ex votos. El primer animal se asocia al dios en algunas aras votivas, como $I R C P \mathrm{n}^{\circ} 495$ y otra anepígrafa de Serpa (IRCP: 805), y aparece también en algunas funerarias como la de Figueira e Barros (Avis, Portalegre) $I R C P \mathrm{n}^{\circ} 448$. Aunque Vasconcellos (1905: 124-131) insistía más en una vertiente curadora ligada a su aspecto ctónico, Encarnação establece una relación ideológica entre la representación funeraria del jabalí y el carácter infernal atribuido generalmente a Endovélico. En la misma línea se mantienen los trabajos más recientes.

Considerando la imprecisión en todos los sentidos (iconográfico, cronológico, funcional) de los relieves y la debilidad de los animales de bronce como únicos indicios posibles de culto a un popular dios lusitano, ya seguramente en época imperial, puede ser interesante tratar de identificar a sus responsables, la población de las minas. La fuente más directa para conocerla es la epigrafía, pero nos lleva ya a época imperial romana y sólo recoge a una ínfima minoría de la población. Las 22 inscripciones procedentes de Riotinto en CILA I $\left(n^{\circ} 28-46\right.$, incluyendo $36 \mathrm{a}$ y $45 \mathrm{a}$ y b) presentan el siguiente panorama:

- seis no tienen onomástica ni datos que permitan identificar personas;

- cinco se refieren a personas de origen no especificado, que puede ser local o no, con onomástica ya latinizada: CILA I n $^{\circ} 32, C I L A$ I n $^{\circ} 35, C I L A$ I ${ }^{\circ} 41, C I L A$ I n ${ }^{\circ} 45$;

— otras cinco son de lusitanos, según indican su origo o su onomástica: $C I L A \operatorname{In}^{\circ} 36, C I L A \operatorname{In}^{\circ} 36 \mathrm{a}, C I L A \mathrm{I}$ $\mathrm{n}^{\circ} 37, C I L A \mathrm{I} \mathrm{n}^{\circ} 38, C I L A \mathrm{I} \mathrm{n}^{\circ} 44$;

— tres más corresponden a talabrigenses, probablemente galaicos (Le Roux 1982: 112 ss.; Pereira 1983: 169 ss.; CILA I: 70 y n. 83), aunque Domergue (1990: 344) sitúa una Talabriga lusitana en Vouga, entre el Duero y el Mondego: $C I L A$ I $^{\circ} 33, C I L A$ I n ${ }^{\circ} 40, C I L A$ I n ${ }^{\circ} 42$;

- y otras tres nombran forasteros de distinto origen: CILA $\operatorname{In}^{\circ} 29, C I L A$ I no $^{\circ} 31, C I L A$ I no 39 .

En total, once foráneos seguros con predominio de lusitanos, frente a cinco dudosos. Si sumamos las de núcleos vecinos como Berrocal y Campofrío, encontramos dos personajes más de onomástica latina y origen desconocido, quizás local: $C I L A$ I n $^{\circ} 51$ y $C I L A$ I n$^{\circ} 52$; y otro posiblemente del N.O., según su pertenencia a un castellum: CILA $\mathrm{I} \mathrm{n}^{\circ} 57$. Ante semejante panorama, que contrasta por ejemplo con el predominio de trabajadores locales en la cuenca minera leonesa (Domergue 1990: 335, 346-348), la población 
local queda muy diluida, aunque el componente céltico no pueda descartarse. Parte de los testimonios religiosos citados debe corresponder a la población emigrante, lusitana y galaica. En esos ámbitos habría que intentar identificar a los dioses conocidos en la zona.

El carácter lusitano de Endovélico, al que el jabalí y la ¿cabra? parecen aludir, y las dudas sobre la población autóctona hacen pensar que el dios ha sido importado por los lusitanos venidos a las minas, cuya procedencia, cuando se indica, es olisiponense y emeritense y que llevan nombres propios del N. del Tajo (ver su dispersión en Francisco 1989: 257). ¿Tenía el culto a Endovélico tanta fuerza que transmitió su nombre al propio lugar? En toda la provincia, incluido el propio Cerro del Andévalo, faltan por completo las inscripciones tan abundantes en Postoloboso y S. Miguel de Mota. En estos dos santuarios los devotos, de las más diversas procedencias, demuestran un grado bastante avanzado de romanización, con abundancia de ciudadanos y onomástica latina (véase el repertorio completo hasta 1984 en $I R C P$ ). Aunque ajeno al panteón romano, Endovélico parece ejercer como aglutinante de una población heterogénea de fondo y romanizada en su aspecto. Contar con una divinidad de tal fuerza "integradora" sería muy útil en una población de composición tan variada como la de un distrito minero. El Cerro del Andévalo es prácticamente equidistante de los dos núcleos más importantes de Huelva, Riotinto y Tharsis, y su radio de influencia podría extenderse en ambas direcciones, sin excluir que en el propio Riotinto existiera un santuario local, a una divinidad también prerromana que no nos atrevemos a identificar.

Sería tentador pensar incluso en un cierto apoyo de las autoridades responsables de las minas, semejante al que muestran los procuratores y legados militares en las minas leonesas a los dioses locales (Diego 1986: $\mathrm{n}^{\circ} 11,13,26-28$ ), aunque carecemos de pruebas. Un impulso artificial con fines de control explicaría, por una parte, la construcción de santuarios en lugares especialmente destacados y a ser posible viejos centros religiosos; por otra, el poco arraigo real del culto, que la ausencia total de inscripciones permite entrever. Destacamos que en los alrededores de Postoloboso, el santuario meseteño de Endovélico, se explota el hierro (Fernández 1973: 230), lo que confirmaría la vinculación entre el dios y la actividad minera, algo habitual en las divinidades ctónicas.

Otro problema de estos posibles exvotos es que no pueden fecharse con la precisión suficiente para establecer la época de desarrollo o expansión del culto. Las fechas son imprecisas incluso en los lugares de origen de los dioses correspondientes, siempre que fuera posible identificar los relieves con el Vestio Alonieco de Lourizán, algo en sí mismo dudoso: s. II-I a.C. para el dios galaico, toda la época imperial para Endovélico en S. Miguel de Mota. De todas formas, deben coincidir con la época de auge de las minas, entre la segunda mitad del s. I y mediados del s. II d.C., cuando la afluencia de emigrantes sería mayor. El jabalí podría ser de época imperial, mientras es casi imposible fechar el otro animal.

En cuanto a los testimonios romanos, el uso religioso de la figura de Silvano y de la gema es dudoso. González y Pérez Macías (1986: 294) relacionan el bronce con la veneración de los esclavos por Silvano, pero es difícil evaluar el volumen de población servil en las minas de Huelva. Como en las minas portuguesas de Vipasca, al parecer en Sotiel Coronada una ley regulaba el trabajo incluyendo el de los esclavos, lo que implica una presencia numerosa (Domergue 1990: 335-342), pero la epigrafía testimonia aún más población libre, trabajadores asalariados. Por otro lado, al ser Silvano un dios de la vegetación y los bosques (véase Pastor 1981) no resulta apropiado en un núcleo minero, donde serían más esperables divinidades ctónicas. A falta de contexto, no sabemos si la figura tuvo alguna función como ex voto o en el culto doméstico, o si era simplemente un objeto funcional. En todo caso y como es habitual en el culto a Silvano, no sobrepasa el ámbito privado, a diferencia de una manifestación colectiva como la dedicatoria a Júpiter.

Algo semejante ocurre con las figurillas de Fortuna y Marte, si bien en esta última su poca calidad parece excluir un uso decorativo, mientras resulta frecuente en los exvotos y figuras de larario. Marte es venerado como Augusto por un devoto anónimo en otro punto de la provincia, Aroche $\left(C I L A \operatorname{In}^{\circ} 1\right)$. Fortuna es habitual en los lararios de todo el Imperio y precisamente sus atributos aparecen en la única gema de la zona que alude a divinidades. Su función como dispensadora de bienes encaja en el ambiente de un centro minero. 
En cuanto a los exvotos anatómicos, son una práctica común a religiones muy diferentes hasta la actualidad. Se suele asignar este carácter a la mano de bronce (Bronces 1990: $218 \mathrm{n}^{\circ}$ 103; Rodríguez Oliva 1993: 96), aunque es más dudosa la divinidad receptora. Una propuesta reciente la relaciona con el probable santuario de Riotinto y el culto a una divinidad oriental, Júpiter Dolicheno, del que en Hispania habría otros testimonios semejantes (Perea 1995, Cuenca 1996: 54-55). Sin embargo, este dios muestra escaso arraigo y nada confirma (excepto la propia mano) que reciba culto en Riotinto. La variedad de orígenes de su población no permite descartar su llegada, pero sería poco probable que se asociara al santuario indígena, del que por otra parte desconocemos con seguridad el titular.

Relacionar la mano -sea exvoto por una curación o representación de una versión oriental de Júpitercon el collegium salutare de Riotinto resulta difícil. Santero (1978: 72) consideraba estos colegios básicamente funerarios, sin funciones médicas o de mutua sanitaria, como sí acepta Domergue (1990: 363) apoyándose en el epíteto salutare. Tampoco sabemos si la fecha de la mano corresponde a la de la lápida, relativamente tardía. En todo caso, ambas son testimonio de creencias atentas al bienestar personal. Incluso, sería posible atribuir la supuesta curación de la mano a Endovélico, que al parecer poseía atribuciones médicas, aumentándose así el número de sus testimonios.

Nos queda un solo dato indiscutible: la dedicatoria del collegium salutare a Júpiter Óptimo Máximo, único epígrafe votivo en la cuenca minera. Éstos escasean en toda la provincia de Huelva, con dos dedicatorias en Aroche: $C I L A \operatorname{In}^{\circ} 5$ a Apolo y Diana y $C I L A \operatorname{In}^{\circ} 1$ a Marte Augusto; y cuatro más en la campiña a dioses de carácter político, la Tríada Capitolina y las divinidades Augustas: $C I L A$ I n$^{\circ}$ 83, a Diana Augusta en Manzanilla; CILA I $n^{\circ} 81$ a Juno Reina en Villalba del Alcor; CILA I $n^{\circ} 73$ a Minerva en Niebla y el ara de culto imperial de Trigueros CILA I ${ }^{\circ} 70$. Los dedicantes son siempre ciudadanos en posición social muy destacada. Todo ello sugiere más relación con quienes vienen a controlar la explotación minera y con las élites locales de la campiña, que con los sectores más humildes.

Por contraste, los objetos aquí estudiados deben pertenecer a los grupos más modestos de la comunidad minera, excepto quizás la gema, la estatuilla de Fortuna y el jabalí. Los restos del poblado del Cerro Salomón (Domergue 1987:241; 1990:361-362) y algunas tumbas de la necrópolis que se extiende hasta La Dehesa (Nerva) evidencian cierta riqueza. Otros restos de poblados son más escasos y dispersos (Rothenberg- Pérez Macías 1987: 380-388) y las necrópolis en la Corta del Lago resultan más pobres (Pérez Macías 1987: 190-191). Sin embargo los propietarios de las viviendas y sepulturas más ricas, quizás los administradores de las minas, no han dejado huellas evidentes de sus creencias.

La situación es radicalmente distinta a la de la otra gran cuenca minera andaluza, la de Castulo, donde se constata una fuerte implantación del culto al emperador y a divinidades siempre del panteón clásico, por parte de la élite local y los libertos ricos (Pastor-Pachón 1982: 339-348; Pastor 1989: 638-641; Blázquez 1984: 301-314). El sustrato ibérico y púnico, de intensa tradición urbana, facilita la adaptación de las estructuras ciudadanas romanas, justificando esta asimilación, ya de época imperial, de la religiosidad oficial en Castulo. Su ambiente coincide con el de las citadas inscripciones en la mitad S. de la provincia de Huelva: dedicatorias siempre en municipios, dedicantes que proceden de Italia como la Rantulana Priscilla que dedica a Diana Augusta en Manzanilla (CILA I n ${ }^{\circ} 83$ ), o la familia responsable de la estatua de Juno Regina en Villalba del Alcor ( $C I L A$ I n ${ }^{\circ} 81$ ); cargos públicos, dioses oficiales, estatuas de plata, etc. La gran epigrafía votiva parece reservada a los grupos dirigentes municipales, más desarrollados en la campiña y en la más importante ciudad de la Sierra, Arucci, que en la cuenca minera.

La dedicatoria del collegium salutare de Riotinto a Júpiter Óptimo Máximo sugiere un ambiente muy diferente. La composición de estos colegios apunta en general a estratos sociales muy inferiores, trabajadores, esclavos o libertos de las minas en este caso. Júpiter Óptimo Máximo es sin duda el dios supremo del panteón romano, pero también el de mayores posibilidades de asimilación con dioses supremos de otros orígenes. Recordemos su aceptación en el N.O. de Hispania y la frecuencia con que se le añaden epítetos indígenas, 
como Anderón (CIL II 2598) o Candiedo (CIL II 2599). En esta región también de economía minera y fuerte presencia militar, Júpiter es venerado como dios supremo asociado a las montañas (de ahí los epítetos alusivos a los montes locales) y con frecuencia sus devotos son libertos imperiales que se ocupan de la administración de las minas (Mangas 1983: 169-171; Penas 1986: 124 ss., 137, 140). Es decir: por un lado, la clásica denominación romana de Júpiter Optimo Máximo es la aportación de quienes vienen como funcionarios imperiales. Su carácter de dios celestial supremo propicia la asimilación con sus equivalentes de los montes locales. En la dedicatoria de Riotinto falta una evidencia semejante, pero en cambio extraña la elección como patrono para un colegio funerario de un dios poco relacionado con ese ámbito (otro ejemplo, de Roma, en Santero 1978: 71). Tales atribuciones serían compatibles con la propuesta sobre Júpiter Dolicheno y sabemos que los cultos orientales gozan de gran aceptación entre las clases populares. Sin embargo resulta más dudoso que, de patrocinar este último dios un colegio funerario con base popular, lo haga bajo la advocación más puramente política del dios supremo del panteón romano.

El texto no se encuentra sobre un pedestal de grandes dimensiones, destinado a una estatua, sino sobre una placa de mármol, que iría adosada a otro soporte. El escribir erróneamente el propio nombre del colegio, con una $\mathrm{M}$ final innecesaria, indica una latinización imperfecta, o medios económicos escasos para recurrir a un taller de mayor calidad. Insistimos en el bajo nivel socioeconómico de la población que conocemos a través de la epigrafía y el predominio de la onomástica indígena. Los componentes del colegio pertenecerían a este ambiente (Blanco 1962: 44; Rodríguez Cortés 1991: 27), lo que nos sitúa ante una manifestación de carácter popular, dedicada a Júpiter como dios supremo de ámbito celestial. El carácter funerario del collegium salutare parece descartar aquí las implicaciones políticas del culto (Delgado 1993), como ya indica Rodríguez Cortés (1991: 23) sobre las dedicatorias privadas a los dioses de la Tríada Capitolina.

En resumen, el estudio de los objetos relacionados con la religión en las minas de Riotinto deja abiertos algunos interrogantes importantes: ¿Quiénes son realmente los dioses prerromanos allí venerados? ¿Cuál es el valor real de las piezas conservadas como testimonio de creencias? Las relativas a dioses indígenas son de identificación insegura y las de dioses romanos se reducen a iconografía de uso dudoso, excepto una inscripción. Insistimos en la falta de epigrafía alusiva a las creencias de la población local y emigrada de Riotinto, tanto funcionarios "de carrera" instalados en la provincia para controlar las minas, como los trabajadores de diversas procedencias. En la cuenca minera leonesa los dedicantes a los dioses, en especial a los clásicos u orientales, son con más frecuencia libertos imperiales con función de procurator metallorum o militares, que los presuntos mineros, gente de onomástica indígena o con estatuto peregrino (remitimos a Diego 1986). La diferencia de nivel económico y cultural es sin duda una explicación posible, pero en las minas de Riotinto estos trabajadores sí aparecen de forma habitual (incluso mayoritaria) en una epigrafía funeraria muy pobre formalmente (Amo 1978:344-345). ¿Por qué escasea de tal modo la epigrafía votiva, cuando en regiones de características parecidas y mayor predominio del componente local se encuentra sin problemas? Quizás deberíamos pensar en diferentes prácticas religiosas, que se expresan mejor mediante el exvoto figurativo que mediante la inscripción.

En principio, carecemos de respuesta segura para la mayoría de estas cuestiones mientras no aparezcan nuevos testimonios. Lo único que podemos proponer es la posible implantación, $i$ artificialmente protegida con fines políticos?, de un dios venido de Lusitania, Endovélico, que de ser cierta se añadiría a los cultos locales; una probable influencia de los trabajadores foráneos, tanto o más numerosos que los de origen local; y un conocimiento más o menos preciso de dioses romanos muy destacados, I.O.M. y Marte. El collegium salutare confirma que el primero de ellos ha conseguido una veneración relativamente amplia, y no precisamente como divinidad política ciudadana, sino en el marco de unas comunidades pobres cuya máxima preocupación no debió ser otra que la supervivencia. 


\section{ABREVIATURAS EMPLEADAS}

Bronces (1990): VV.AA.: Los bronces romanos en España. Madrid.

Celtas y túrdulos (1995): VV.AA.: Celtas y túrdulos: la Beturia. Mérida.

CIL II: HÜBNER, E. (1869 y 1890): Corpus Inscriptionum Latinarum, vol. II: Inscriptiones Hispaniae

Latinae; vol. II Supplementum. Berlín.

CILA I: GONZÁLEZ, J. (1989): Corpus de inscripciones latinas de Andalucía, I. Huelva. Sevilla.

EREP: GARCÍA Y BELLIDO, A. (1949): Esculturas romanas de España y Portugal. Madrid.

ILER: VIVES, J. M ${ }^{\mathrm{a}}$ (1970): Inscripciones latinas de la España romana. Barcelona.

IRCP: ENCARNAÇÃO, J. d' (1984): Inscrições romanas do Conventus Pacensis. Coimbra.

\section{BIBLIOGRAFÍA}

ACUÑA, P. (1975): Esculturas militares en la España romana. Madrid.

ALMAGRO-GORBEA, M. (1990): "Los celtas en la Península Ibérica: origen y personalidad cultural", Los celtas: Hispania y Europa. Madrid: 121-173

AMO, M. del (1978): "Notas sobbre epigrafía romana en la provincia de Huelva", Huelva Arqueológica IV: $344-345$.

BERROCAL, L. (1989-90): “Cambio cultural y romanización en el Suroeste peninsular”, Anas 2-3: 103-121.

- (1992): Los pueblos célticos del Suroeste de la Península Ibérica. Complutum, Serie Extra ${ }^{\circ} 2$. Madrid. (1995): "La Beturia: definición y caracterización de un territorio prerromano", Celtas y túrdulos: la Beturia. Mérida: 151-204.

BLANCO, A. (1962): “Antigüedades de Riotinto”, Zephyrus XIII: 31-45.

y ROTHENBERG, B. (1981): Exploración arqueometalúrgica de Huelva. Barcelona.

BLÁZQUEZ, J. Ma (1977): Imagen y mito. Madrid.

(1983): Religiones prerromanas. Madrid.

(1984): "Cástulo a través de sus inscripciones latinas", Épigraphie hispanique: problèmes de méthode et d'édition. París: 301-314.

BOUZA, F. (1946): "Vestio Alonieco, nueva divinidad galaica", Archivo Español de Arqueología 19: 110-116.

CANTO, A. Ma (1995): "La Beturia Céltica: introducción a su epigrafía”, Celtas y túrdulos: la Beturia. Mérida: 293-329.

CASAL, R. (1990): Entalles romanos del Museo Arqueológico Nacional. Madrid.

CEÁN, J. A. (1832): Sumario de las antigüedades romanas que hay en España. Madrid.

CUENCA, J. Ma (1996): "Materiales de un santuario hispanorromano en Riotinto (Huelva)", Revista de Arqueología 179: 50-57.

DELGADO, J. A. (1993): "El culto a Júpiter, Juno y Minerva entre las élites béticas durante el Alto Imperio Romano", Gerión 11: 337-363.

DIEGO, F. (1986): Inscripciones latinas de la provincia de León. León.

DOMERGUE, C. (1987): Catalogue des mines et des fonderies antiques de la Péninsule Ibérique. Madrid. (1990): Les mines de la Péninsule Ibérique dans l'Antiquité romaine. Roma.

FERNÁNDEZ GÓMEZ, F. (1973): "El santuario de Postoloboso (Candeleda, Ávila)", NAHArqueología 2: 167-270.

FRANCISCO, J. de (1989): Conquista y romanización de Lusitania. Salamanca.

GAMITO, M ${ }^{\mathrm{a}}$ T. Júdice (1988): Social complexity in Southwest Iberia 800-300 B.C. The case of Tartessos. B.A.R. International Series $n^{\circ} 493$. Oxford. 
GARCÍA Y BELLIDO, A. (1942): Fenicios y cartagineses en Occidente. Madrid.

GARCÍA MORENO, L. (1971): “La Beturia: un problema geográfico de la España antigua”, Archivo Español de Arqueología 44: 86-108.

GONZÁLEZ, J. y PÉREZ MACÍAS, J. A. (1986): “La romanización de Huelva”, Huelva y su provincia, vol. II. Cádiz: 269 ss.

GORROCHATEGUI, J. (1987): "En torno a la clasificación del lusitano", IV Coloquio sobre Lenguas y Culturas Paleohispánicas (Vitoria, 1985). Veleia 2-3: 77-91.

(1990): "Las lenguas de los pueblos paleohispánicos", Los celtas: Hispania y Europa. Madrid: 409-429.

LE ROUX, P. (1982): L'armée romaine. París.

LORRIO, A. (1995): "Celtas y celtíberos en la Península Ibérica”, Celtas y túrdulos: la Beturia. Mérida: 77-126.

LUZÓN, J. Ma (1974): “Antigüedades romanas en la provincia de Huelva”, Huelva, Prehistoria y Antigüedad. Madrid: 271-303.

MANGAS, J. (1983): “La difusión de la religión romana en Asturias", Indigenismo y romanización en el Conventus Asturum. Oviedo: 165-177.

MARCO, F. (1990): "La religiosidad en la Céltica hispana", Los celtas: Hispania y Europa. Madrid: 477-512.

MARTÍNEZ, F., PAVÓN, P. y LORENZO, J. P. (1991): “Aportación al estudio de los entalles romanos: tres piezas del Cerro del Moro (Nerva, Huelva)" Cuadernos del Suroeste 2: 147-154.

ORIA, M. y ESCOBAR, B. (1994): "Dioses romanos en bronce de la Bética Occidental: propuesta de interpretación”, Arqueología en el entorno del Bajo Guadiana. Huelva: 441-467.

PASTOR, M. (1981): “El culto al dios Silvano en Hispania ¿innovación o sincretismo?", Memorias de Historia Antigua V: 103-114.

- (1989): "Société, religion et épigraphie dans le municipium de Castulo", Latomus XLVIII-3:

— y PACHÓN, J. A. (1982): "La religión romana en Cástulo a través de su epigrafía”, I Congreso Andaluz de Estudios Clásicos. Jaén: 339-348.

PENAS, Ma A. (1986): “Los dioses de la montaña", en BERMEJO BARRERA, J. C.: Mitología y mitos de la España prerromana 2. Madrid: 117-140.

PEREA, S. (1995): "Las manos de Júpiter Dolicheno. Un nuevo ejemplar en Riotinto (Huelva)", Hispania Antiqua. XIX: 217-231.

PEREIRA, G. (1983): "Los castella y las comunidades de Gallaecia", Actas II Seminario de Arqueología del Noroeste (Santiago, 1990). Madrid: 169 ss.

PÉREZ MACÍAS, J. A. (1987): "Excavación de urgencia en la necrópolis del Stock de Gossan (Riotinto, Huelva)", Anuario Arqueológico de Andalucía 1985, vol. III: 190-191.

RODRÍGUEZ CORTÉS, J. (1991): Sociedad y religión clásica en la Bética romana. Salamanca.

RODRÍGUEZ OLIVA, P. (1993): "Ciclos escultóricos en la casa y en la ciudad de la Bética", Actas de la I Reunión sobre Escultura Romana en Hispania (Mérida, 1992). Mérida: 23-61.

ROTHENBERG, B. y PÉREZ MACÍAS, J. A. (1987): “Excavación arqueológica sistemática en el yacimiento Corta del Lago (Riotinto, Huelva)", Anuario Arqueológico de Andalucía 1986, vol. II: 380-388.

SANTERO, J. M (1978): Asociaciones populares en la Hispania romana. Sevilla.

SILLIERES, P. (1981): "Vía romana y uillae en la zona de La Palma del Condado (Huelva)", Habis 12: 409-418.

(1990): Les voies de communication de l'Hispanie méridionale. París.

TRANOY, A. (1981): La Galice romaine. París.

VASCONCELLOS, J. Leite de (1905): Religiões de Lusitânia, vol. II. Lisboa. 


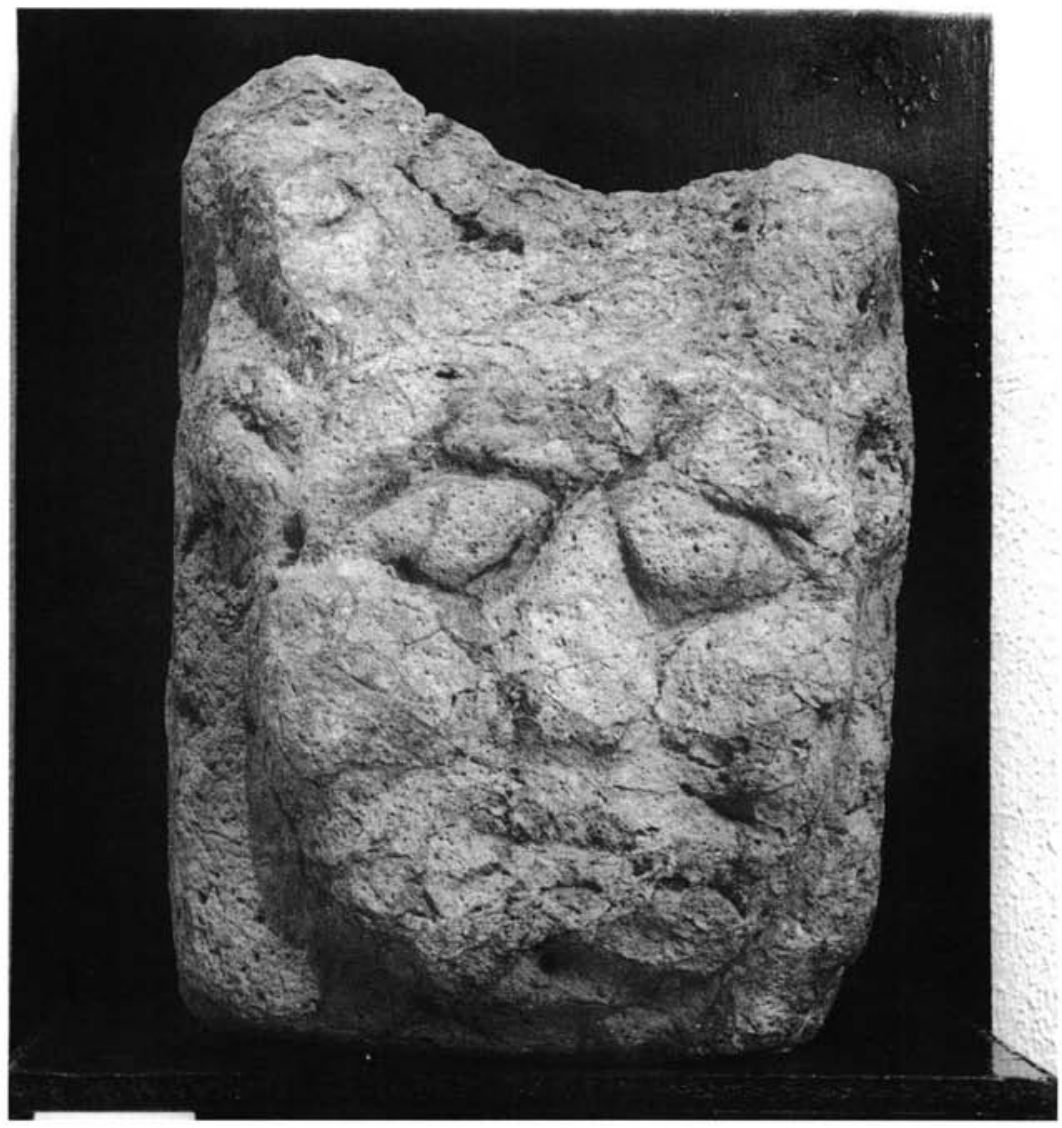

Lámina I: Cabeza de piedra, Cerro Salomón (Riotinto, Huelva). Museo Minero de Riotinto, $\mathrm{n}^{\circ}$ inv. 237 (Foto M. Oria). 


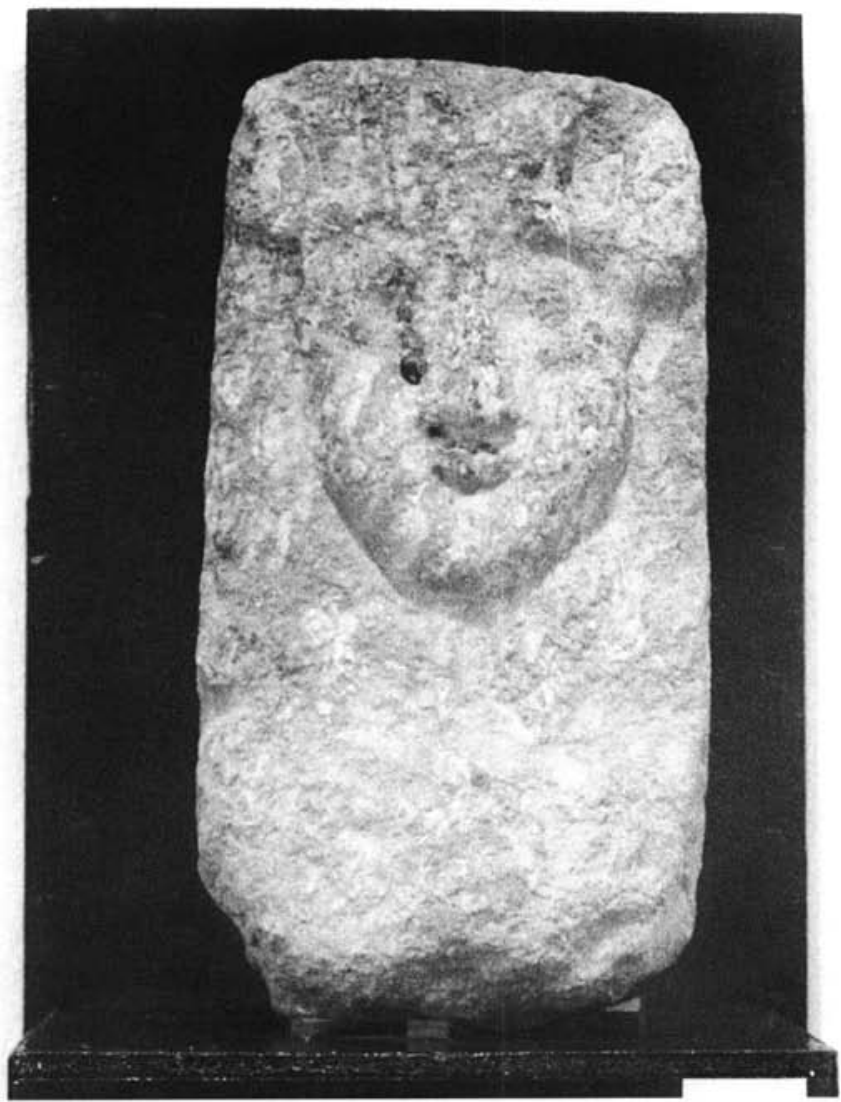

Lámina II: Cabeza de piedra, Cerro Salomón (Riotinto, Huelva), Museo Minero de Riotinto, $\mathrm{n}^{\circ}$ inv, 238 (Foto M. Oria). 


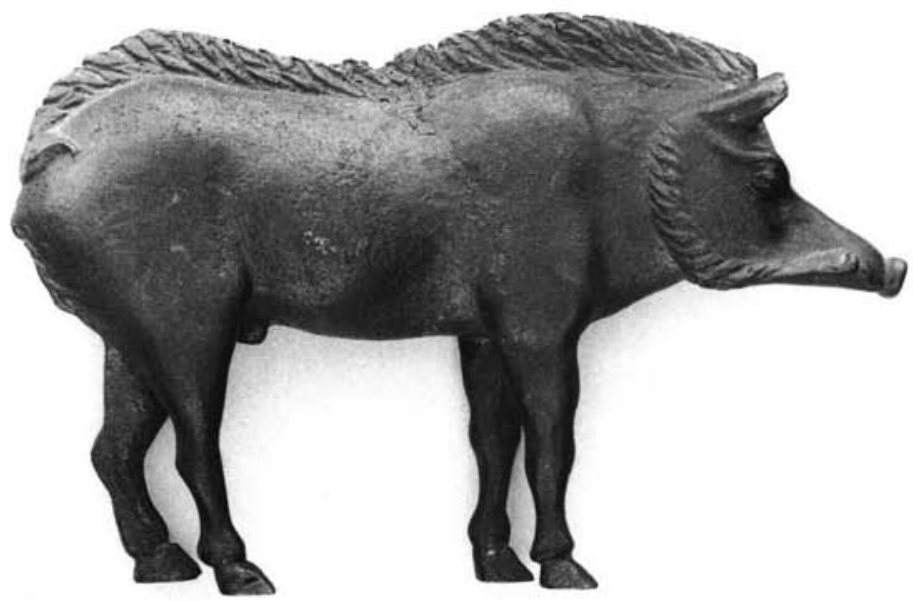

Lámina III: Jabalí de bronce, Riotinto (Huelva). Reproducción conservada en el Museo Provincial de Huelva (Foto M. Oria).

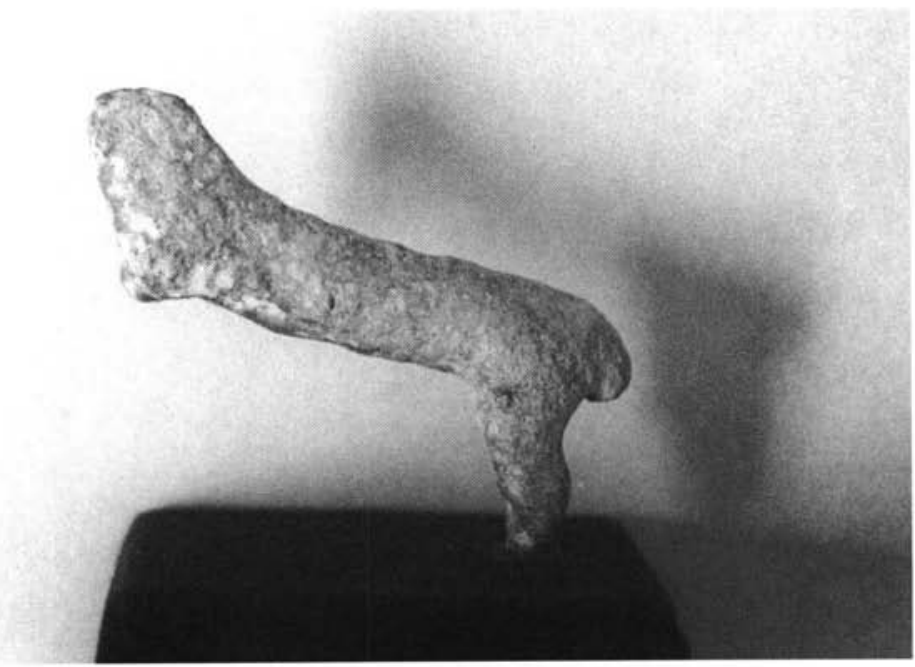

Lámina IV: Figura animal de bronce, Riotinto (Huelva). Museo Minero de Riotinto, $\mathrm{n}^{\circ}$ inv. 2717 (Foto M. Oria). 


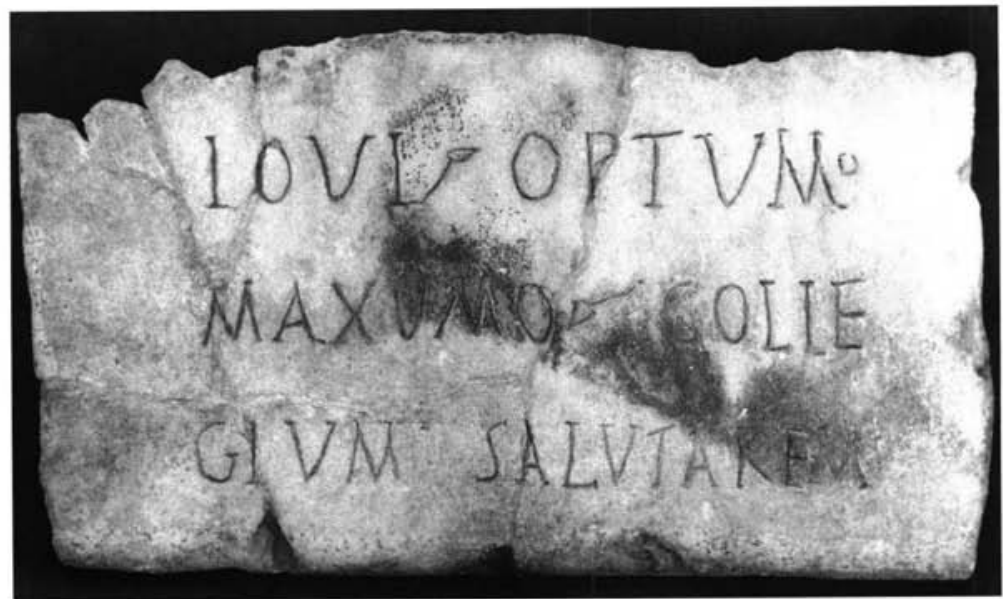

Lámina V: Dedicatoria del Collegium Salutare de Riotinto a Júpiter Óptimo Máximo. Museo Provincial de Huelva (Foto M. Oria)

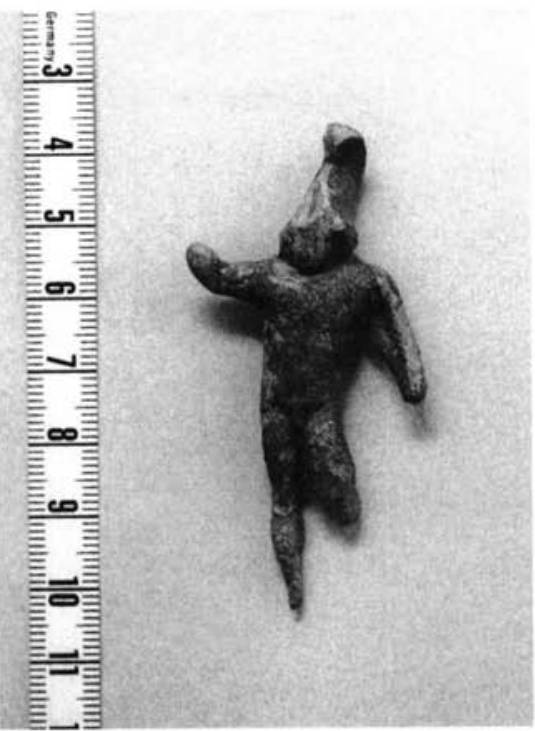

Lámina VI: Marte de bronce, La Marismilla (Riotinto, Huelva). Museo Minero de Riotinto, $\mathrm{n}^{\circ}$ inv. 1036 (Foto M. Oria).

SPAL 6 (1997)

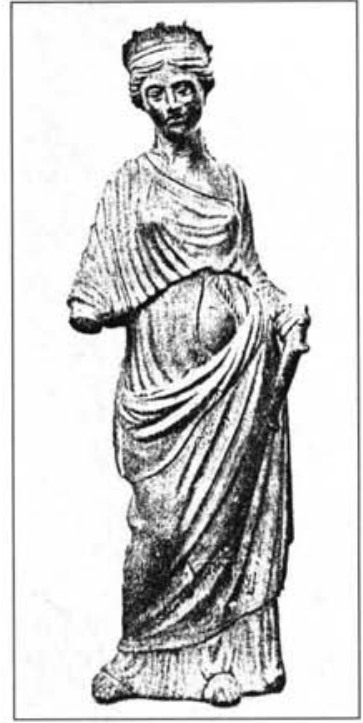

Lámina VII: Fortuna de bronce, Riotinto (Huelva). Paradero desconocido (Imagen reproducida de W. G. Nash: The Rio Tinto mine, its history and romance, Londres 1904, Lám. s/n $\mathrm{n}^{\circ}$ entre pp. 48-49).

ISSN: 1133-4525 ISSN-e: 2255-3924

http://dx.doi.org/10.12795/spal.1997.i6.12 
Lámina VIII: Mano de bronce, Riotinto (Huelva). Museo Provincial de Huelva, $\mathrm{n}^{\circ}$ inv. 3.866 (Foto M. Oria).

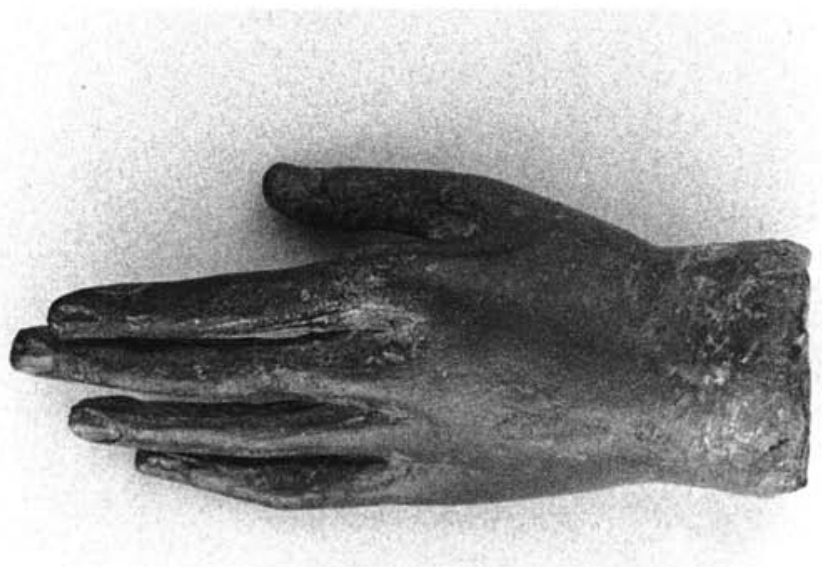

Lámina IX: Dorso de la misma mano (Foto M. Oria).

ISSN: 1133-4525 ISSN-e: 2255-3924

http://dx.doi.org/10.12795/spal.1997.i6.12 


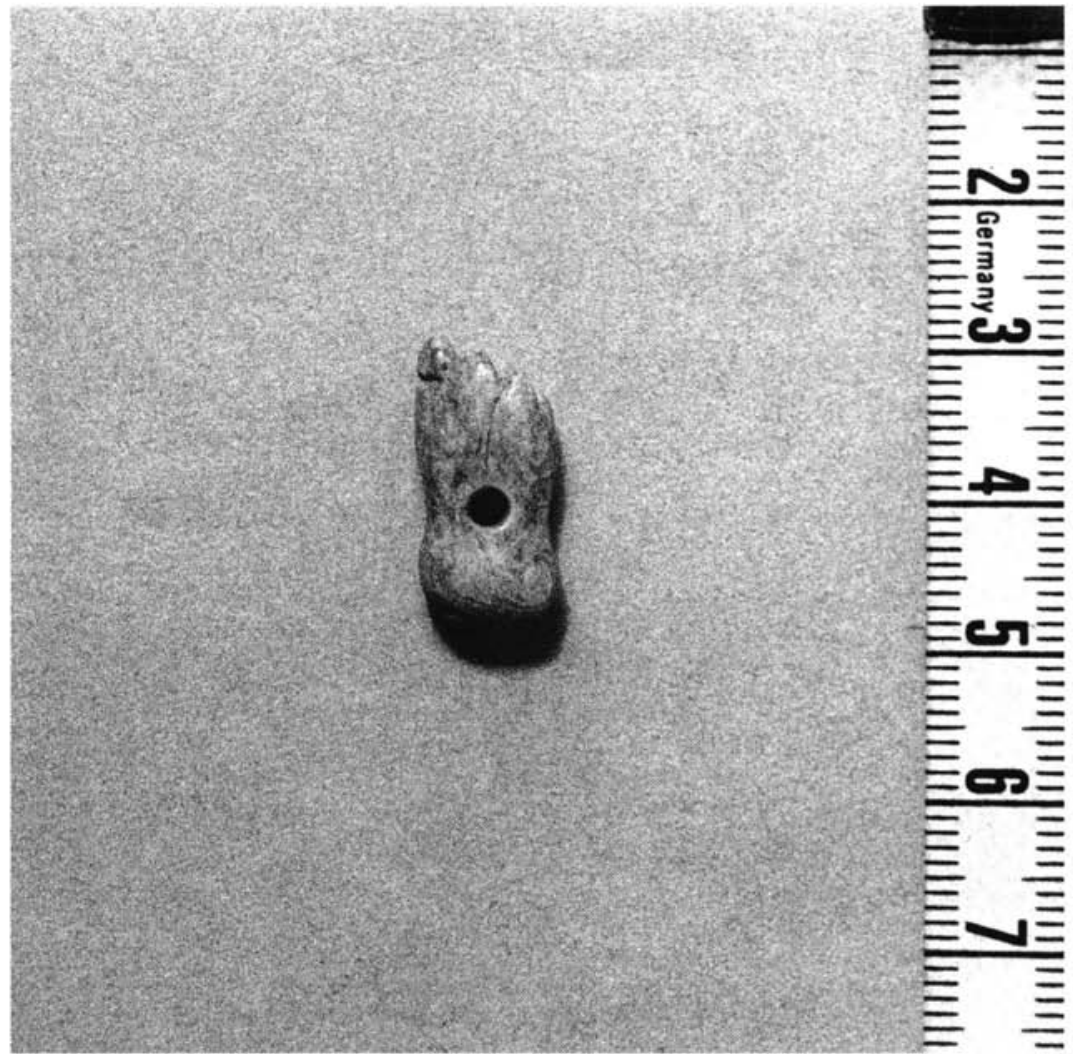

Lámina X: Colgante en forma de pie de hueso, Riotinto (Huelva). Museo Minero de Riotinto, $\mathrm{n}^{\circ}$ inv. 2338 (Foto M. Oria). 